\title{
Fluviicola taffensis gen. nov., sp. nov., a novel freshwater bacterium of the family Cryomorphaceae in the phylum 'Bacteroidetes'
}

Correspondence
John C. Fry
Fry@Cardiff.ac.uk

\author{
Louise A. O'Sullivan, ${ }^{1}$ Joachim Rinna, ${ }^{2}$ Gavin Humphreys, ${ }^{1}$ \\ Andrew J. Weightman ${ }^{1}$ and John C. Fry ${ }^{1}$ \\ ${ }^{1}$ Cardiff School of Biosciences, Cardiff University, Main Building, Park Place, Cardiff CF10 3TL,
UK \\ ${ }^{2}$ School of Earth, Ocean and Planetary Sciences, Cardiff University, Main Building, Park Place, \\ Cardiff CF10 3YE, UK
}

\begin{abstract}
A novel, strictly aerobic, Gram-negative, yellow-orange-pigmented, motile, catalase-positive, oxidase-negative bacterium, RW262 ${ }^{\top}$, was isolated from water of the River Taff, Cardiff, UK, during January 2000. Phylogenetic analysis of the $16 \mathrm{~S}$ rRNA gene indicated that strain RW262 ${ }^{\top}$ was a member of the family Cryomorphaceae within the phylum 'Bacteroidetes'. The DNA $\mathrm{G}+\mathrm{C}$ content of strain RW $262^{\top}$ was $37 \cdot 2 \mathrm{~mol} \%$. The predominant fatty acid was the branched-chain saturated fatty acid i15:0 (44.2\%). On the basis of polyphasic analysis of phenotypic, chemotaxonomic, genotypic and phylogenetic characteristics, it is proposed that this freshwater bacterium represents a novel genus and species within the family Cryomorphaceae, Fluviicola taffensis gen. nov., sp. nov. The type strain is $\mathrm{RW}_{262}{ }^{\top}\left(=\mathrm{NCIMB} 13979^{\top}=\mathrm{DSM}\right.$ $\left.16823^{\top}\right)$.
\end{abstract}

Molecular phylogenetic approaches based on analysis of the $16 \mathrm{~S}$ rRNA gene sequence have revealed that members of the phylum 'Bacteroidetes' are highly abundant in aquatic environments (DeLong et al., 1993; Glöckner et al., 1999; Cottrell \& Kirchman, 2000; O’Sullivan et al., 2002, 2004). However, the majority of the $16 \mathrm{~S}$ rRNA gene sequences of members of 'Bacteroidetes' isolated from aquatic habitats are most closely related to those of uncultivated bacteria, indicating that a large amount of potentially interesting bacterial diversity has yet to be cultured (O'Sullivan et al., 2004). In the past few years there has been an increase in the descriptions of new genera of aquatic origin within the phylum 'Bacteroidetes', including Reichenbachia, Vitellibacter, Mesonia and Ulvibacter (Nedashkovskaya et al., 2003a, b, c, 2004, respectively), Belliella (Brettar et al., 2004), Gillisia (Van Trappen et al., 2004), Kordia (Sohn et al., 2004), Arcicella (Nikitin et al., 2004) and Formosa (Ivanova et al., 2004).

Published online ahead of print on 3 June 2005 as DOI 10.1099/ ijs.0.63736-0.

The GenBank/EMBL/DDBJ accession number for the $16 \mathrm{~S}$ rRNA gene sequence of Fluviicola taffensis RW262 ${ }^{\top}$ is AF493694.

Micrographs of cells of strain RW $262^{\top}$ and a table showing complete whole-cell fatty acid profiles of RW $262^{\top}$ and the type species of other members of the family Cryomorphaceae are available as supplementary material in IJSEM Online.
The novel family Cryomorphaceae has recently been described as containing four genera of marine origin: Brumimicrobium, Cryomorpha and Crocinitomix (Bowman et al., 2003), and Owenweeksia (Lau et al., 2005). According to $16 \mathrm{~S}$ rRNA gene phylogeny, the family Cryomorphaceae branches between the families Flavobacteriaceae and Bacteroidaceae (Bowman et al., 2003). It also exhibits greatest phenotypic similarity to the well-defined family Flavobacteriaceae (Bernardet et al., 1996). On the basis of polyphasic taxonomic data and in adherence with the proposed minimal standards for describing new taxa of the closely related family Flavobacteriaceae (Bernardet et al., 2002), we describe a novel freshwater member of the family Cryomorphaceae, Fluviicola taffensis gen. nov., sp. nov.

Strain RW262 ${ }^{\mathrm{T}}$ was isolated from water of the River Taff (Cardiff, UK; Ordnance Survey map reference SO 783 165) in January 2000, after 6 days incubation at $20^{\circ} \mathrm{C}$ on CYT agar ( $1 \mathrm{~g}$ pancreatic digest of casein, $0.5 \mathrm{~g} \mathrm{CaCl}_{2} .2 \mathrm{H}_{2} \mathrm{O}$, $0.5 \mathrm{~g} \mathrm{MgSO}_{4} .7 \mathrm{H}_{2} \mathrm{O}, 0.5 \mathrm{~g}$ yeast extract and $15 \mathrm{~g}$ purified agar, per litre distilled water; $\mathrm{pH} 7 \cdot 2$; Holmes, 1992). The strain was subsequently purified on Plate Count agar (PCA; Oxoid) and stored at $-80{ }^{\circ} \mathrm{C}$ in liquid medium supplemented with $20 \%(\mathrm{v} / \mathrm{v})$ glycerol. Strain RW262 ${ }^{\mathrm{T}}$ was selected for further investigation based on the results of $16 \mathrm{~S}$ rRNA gene-targeted oligonucleotide hybridizations described in a previous study (O'Sullivan et al., 2004). 
The following phenotypic tests were performed on strain RW $262^{\mathrm{T}}$ and Crocinitomix catalasitica NCIMB $1418^{\mathrm{T}}$ as a reference. Unless otherwise stated, the strains were revived from freezer stocks at $20^{\circ} \mathrm{C}$ on either nutrient agar (NA; Oxoid) or PCA prior to investigation. The agar used to grow Crocinitomix catalasitica was supplemented with artificial sea water $\left(24.7 \mathrm{~g} \mathrm{NaCl}, 0.7 \mathrm{~g} \mathrm{KCl}, 6.3 \mathrm{~g} \mathrm{MgSO}_{4} .7 \mathrm{H}_{2} \mathrm{O}\right.$, $4.6 \mathrm{~g} \mathrm{MgCl}_{2} \cdot 6 \mathrm{H}_{2} \mathrm{O}, 1 \mathrm{~g}$ anhydrous $\mathrm{CaCl}_{2}$ and $0.2 \mathrm{~g}$ $\mathrm{NaHCO}_{3}$, per litre distilled water). Gram-testing was by the $\mathrm{KOH}$ method (Gregerson, 1978) and flexirubin pigments were determined according to Fautz \& Reichenbach (1980). Growth on Tryptone Soya agar (TSA; Oxoid), Marine agar 2216 (MA2216; Difco), MacConkey agar and Cetrimide agar (Oxoid) was assessed after 1 week. Cell size and gliding motility of strain RW $262^{\mathrm{T}}$ was established by phase-contrast microscopy of colonies after cultivation (3 days) under high humidity on agar. For scanning electron microscopy, RW262 ${ }^{\mathrm{T}}$ cells were fixed $(1 \mathrm{~h}, 3 \%$ glutaraldehyde), washed $(0 \cdot 1 \mathrm{M}$ cacodylate buffer, $\mathrm{pH} 7 \cdot 5)$, postfixed $\left(1 \% \mathrm{OsO}_{4}\right)$, dehydrated in ethanol, critical-point dried and coated with gold. Temperature and salinity requirements were determined by incubation on NA at 4,16 , 30 and $37^{\circ} \mathrm{C}$ and with $0,2 \cdot 5,5$ and $10 \% \mathrm{NaCl}$, respectively. Individual colony formation indicated positive results and growth without colony formation indicated weakly positive results. Standard methods (Smibert \& Krieg, 1994) were used for oxygen requirements (thioglycollate medium), oxidase and catalase activity, DNA hydrolysis (DNASE agar), starch hydrolysis (NA plus $1 \mathrm{~g}$ starch $1^{-1}$ ) and xylanase activity (NA plus $4 \mathrm{~g}$ birch wood xylan $\mathrm{l}^{-1}$ ). Nitrate and nitrite reduction, indole production, urease activity, and hydrolysis of Tween 80, gelatin and arginine were analysed according to Cowan \& Steel (1975). Strains were also characterized using an API 20NE kit (bioMérieux), according to the manufacturer's instructions, except that the incubation was performed at $20^{\circ} \mathrm{C}$ and Crocinitomix catalasitica was inoculated in artificial sea water containing $1 \mathrm{~g}$ Casamino acids $~^{-1}$ and $1 \mathrm{ml}$ trace elements $\mathrm{l}^{-1}(2 \cdot 85 \mathrm{~g}$ $\mathrm{H}_{3} \mathrm{BO}_{3} \mathrm{l}^{-1}, 1.8 \mathrm{~g} \mathrm{MnCl}_{2} .4 \mathrm{H}_{2} \mathrm{O} \mathrm{l} \mathrm{l}^{-1}, 1.36 \mathrm{~g} \mathrm{FeSO}_{4} \mathrm{l}^{-1}$, $26 \cdot 9 \mathrm{mg} \mathrm{CuCl} \cdot 2 \mathrm{H}_{2} \mathrm{O} \mathrm{l}^{-1}, 20 \cdot 8 \mathrm{mg} \mathrm{ZnCl}_{2} \mathrm{l}^{-1}, 40 \cdot 4 \mathrm{mg}$ $\mathrm{CoCl}_{2} \cdot 6 \mathrm{H}_{2} \mathrm{O} \mathrm{l}^{-1}, 25 \cdot 2 \mathrm{mg} \mathrm{Na} \mathrm{MoO}_{4} \cdot 2 \mathrm{H}_{2} \mathrm{O} \mathrm{l}^{-1}$ and $1 \cdot 77 \mathrm{~g}$ sodium tartrate $1^{-1}$ ). Antimicrobial susceptibility was assessed with antibiotic diffusion discs (Mast Diagnostics) with ampicillin $(10 \mu \mathrm{g})$, kanamycin $(30 \mu \mathrm{g})$, penicillin $\mathrm{G}$ (10 units), chloramphenicol $(10 \mu \mathrm{g})$, streptomycin $(10 \mu \mathrm{g})$, tetracycline $(10 \mu \mathrm{g})$ and rifampicin $(5 \mu \mathrm{g})$.

Fatty acid composition was determined with Crocinitomix catalasitica cultivated to confluence on MA2216, and strain RW $262^{\mathrm{T}}$ cultivated on the equivalent of MA2216 but without $\mathrm{NaCl}\left(\mathrm{g} \mathrm{l}^{-1}: 5\right.$ peptone, 1 yeast extract, $0 \cdot 5$ $\mathrm{CaCl}_{2} \cdot 2 \mathrm{H}_{2} \mathrm{O}$ and $\left.0.5 \mathrm{MgSO}_{4} \cdot 7 \mathrm{H}_{2} \mathrm{O}\right)$. Strains were grown at $20{ }^{\circ} \mathrm{C}$ for $72 \mathrm{~h}$, harvested in PBS (Sigma) and freeze-dried. Fatty acid analyses followed the procedure described in the Microbial Identification System protocol (MIDI; http:// www.midi-inc.com), and therefore represent the whole fatty acid composition of the cell hydrolysate. More-detailed analyses with other methods (Serrano-Carreon et al., 1992) showed no significant difference between hydrolysate fatty acid and phospholipid-derived fatty acid (PLFA) compositions, indicating that most fatty acids were derived from PLFAs.

The DNA base composition of strain RW $262^{\mathrm{T}}$ was determined at the German Collection of Microorganisms and Cell Cultures (DSMZ; Braunschweig, Germany). DNA was isolated using a French pressure cell (Thermo Spectronic) and purified (Cashion et al., 1977). The G+C content was determined by HPLC (Mesbah et al., 1989). The 16S rRNA gene of strain RW262 ${ }^{\mathrm{T}}$ was PCR amplified (O'Sullivan et al., 2004) from a small amount of purified colony biomass by using two sets of primers (27F, 1392R and 27F, 1492R; Lane, 1991). The PCR product obtained using primers $27 \mathrm{~F}$ and $1392 \mathrm{R}$ was purified and sequenced (O'Sullivan et al., 2004), and the product obtained with primers $27 \mathrm{~F}$ and $1492 \mathrm{R}$ was cloned by using the TOPO TA system (Invitrogen) and sequenced with primers M13F and M13R (O'Sullivan et al., 2002). A consensus from six overlapping sequences was compared with those most similar to RW $262^{\mathrm{T}}$ in the GenBank database, including representative type strains from four families of the phylum 'Bacteroidetes'. The CLUSTAL $\mathrm{W}$ alignment (Thompson et al., 1994) was trimmed to $1300 \mathrm{bp}$, evolutionary distances were calculated and a phylogenetic tree was constructed (O'Sullivan et al., 2004).

Strain RW262 ${ }^{\mathrm{T}}$ was aerobic, Gram-negative, motile by gliding and flexirubin-pigmented. Cells were long flexible rods with rounded ends, $0 \cdot 4-0.5 \mu \mathrm{m}$ in diameter and $1 \cdot 5-5 \cdot 7 \mu \mathrm{m}$ in length. Rarer longer filaments when observed were of up to $51 \mu \mathrm{m}$ in length (see the supplementary figure in IJSEM Online). After 7 days on PCA at $20^{\circ} \mathrm{C}$, flat, transparent, shiny colonies, $1-5 \mathrm{~mm}$ in diameter, with a yellow-orange colour and creamy consistency, were produced. Growth occurred at 4 and $20^{\circ} \mathrm{C}$, but not in the presence of $\mathrm{Na}^{+}$ions. Growth occurred on NA, PCA, TSA and DNASE agar, but not on MA2216, MacConkey agar or Cetrimide agar. The strain was catalase-positive, hydrolysed DNA and weakly hydrolysed gelatin. It was negative for nitrate and nitrite reduction; indole production; oxidase, $\beta$ galactosidase, urease and xylanase activity; hydrolysis of agar, arginine, aesculin and starch; and acid production from carbohydrates. The strain could not utilize glucose, arabinose, mannose, mannitol, $\mathrm{N}$-acetylglucosamine, maltose, gluconate, caprate, adipate, malate, citrate or phenyl acetate. It was resistant to chloramphenicol, streptomycin and kanamycin, but was susceptible to penicillin G, ampicillin, rifampicin and tetracycline.

The whole-cell fatty acid composition of strain RW $262^{\mathrm{T}}$ is shown in Table 1 (taken from the supplementary table in IJSEM Online). The predominant cellular fatty acid was i15: $0(44 \cdot 2 \%)$. The $\mathrm{G}+\mathrm{C}$ content of the genomic DNA of strain RW $262^{\mathrm{T}}$ was $37 \cdot 2 \mathrm{~mol} \%$. The phylogenetic position of strain RW $262^{\mathrm{T}}$ was determined by analysis of the almostcomplete $16 \mathrm{~S}$ rRNA gene sequence. The greatest sequence similarity observed was with members of the families 
Table 1. Major whole-cell fatty acids that differentiate $F$. taffensis $R W 262^{\top}$ from type species of the genera Brumimicrobium, Cryomorpha, Crocinitomix and Owenweeksia of the family Cryomorphaceae

Strains: 1, RW262 ${ }^{\mathrm{T}}$ (data from this study); 2a, Crocinitomix catalasitica NCIMB $1418^{\mathrm{T}}$ (this study); $2 \mathrm{~b}$, Crocinitomix catalasitica NCIMB $1418^{\mathrm{T}}$ (Bowman et al., 2003); 3, B. glaciale $\mathrm{IC} 156^{\mathrm{T}}$ (Bowman et al., 2003); 4, Cryomorpha ignava $1-22^{\mathrm{T}}$ (Bowman et al., 2003); 5, O. hongkongensis UST20020801 ${ }^{\mathrm{T}}$ (Lau et al., 2005). In this study, strain $\mathrm{RW}_{262^{\mathrm{T}}}$ and Crocinitomix catalasitica were grown on MA2216 at $20^{\circ} \mathrm{C}$ for 3 days (without $\mathrm{NaCl}$ for $\mathrm{RW} 262^{\mathrm{T}}$ ), whereas in the study by Bowman et al. (2003) Crocinitomix catalasitica, B. glaciale and Cryomorpha ignava were grown on MA2216 at $10-12{ }^{\circ} \mathrm{C}$ for 3-5 days. O. hongkongensis was grown on MA2216 at $10^{\circ} \mathrm{C}$ for 5 days.,$-<0 \cdot 01 \%$ detected.

\begin{tabular}{|c|c|c|c|c|c|c|}
\hline \multirow[t]{2}{*}{ Fatty acid } & \multicolumn{6}{|c|}{ Fatty acid content (\% of total) } \\
\hline & 1 & $2 a$ & $2 \mathbf{b}$ & 3 & 4 & 5 \\
\hline \multicolumn{7}{|c|}{ Saturated fatty acids } \\
\hline $15: 0$ & $7 \cdot 5$ & $19 \cdot 2$ & $29 \cdot 3$ & $2 \cdot 9$ & $0 \cdot 8$ & - \\
\hline Sum & $13 \cdot 9$ & $21 \cdot 5$ & $31 \cdot 4$ & $7 \cdot 1$ & $1 \cdot 7$ & $0 \cdot 3$ \\
\hline \multicolumn{7}{|c|}{ Saturated branched-chain fatty acids } \\
\hline i14:0 & - & - & - & $0 \cdot 8$ & $13 \cdot 8$ & - \\
\hline $\mathrm{i} 15: 0$ & $44 \cdot 2$ & $24 \cdot 5$ & $36 \cdot 3$ & $36 \cdot 4$ & $7 \cdot 8$ & $18 \cdot 7$ \\
\hline $\mathrm{i} 15: 1$ & - & - & - & - & - & $28 \cdot 0$ \\
\hline Sum & $45 \cdot 3$ & $24 \cdot 7$ & $36 \cdot 7$ & $43 \cdot 4$ & $35 \cdot 2$ & $47 \cdot 2$ \\
\hline \multicolumn{7}{|c|}{ Unsaturated branched-chain fatty acids } \\
\hline $\mathrm{i} 15: 1 \omega 10 c$ & $11 \cdot 8$ & $17 \cdot 6$ & $10 \cdot 9$ & - & $7 \cdot 1$ & - \\
\hline $\mathrm{a} 15: 1 \omega 10 c$ & - & - & - & $45 \cdot 0$ & $8 \cdot 2$ & - \\
\hline i17 : $1 \omega 9 c$ & - & - & - & - & - & $7 \cdot 3$ \\
\hline Sum & $13 \cdot 6$ & $20 \cdot 4$ & $12 \cdot 8$ & $45 \cdot 9$ & $25 \cdot 0$ & $8 \cdot 6$ \\
\hline \multicolumn{7}{|c|}{ Monounsaturated fatty acids } \\
\hline $15: 1 \omega 11 c$ & $1 \cdot 2$ & $19 \cdot 2$ & $8 \cdot 3$ & - & - & - \\
\hline $16: 1 \omega 12 c$ & $4 \cdot 9$ & $6 \cdot 3$ & $4 \cdot 4$ & - & - & - \\
\hline Sum & $6 \cdot 8$ & $29 \cdot 0$ & $14 \cdot 8$ & $3 \cdot 6$ & $0 \cdot 0$ & $0 \cdot 3$ \\
\hline \multicolumn{7}{|c|}{ Hydroxy fatty acids } \\
\hline 2-OH i14:0 & - & - & - & - & $6 \cdot 7$ & - \\
\hline 2-OH i15:0 & $3 \cdot 5$ & - & - & - & $1 \cdot 6$ & - \\
\hline $2-\mathrm{OH}$ a15:0 & - & - & - & - & $18 \cdot 4$ & - \\
\hline $3-\mathrm{OH} 16: 0$ & - & - & - & - & $2 \cdot 9$ & - \\
\hline 3-OH i17:0 & $12 \cdot 3$ & $4 \cdot 9$ & $3 \cdot 3$ & - & - & $18 \cdot 0$ \\
\hline Sum & $20 \cdot 4$ & $5 \cdot 4$ & $4 \cdot 3$ & $0 \cdot 0$ & $36 \cdot 4$ & $28 \cdot 3$ \\
\hline
\end{tabular}

Cryomorphaceae and Flavobacteriaceae of the phylum 'Bacteroidetes'. The 16S rRNA gene sequence of strain RW $262^{\mathrm{T}}$ was $90 \%$ similar to that of Ornithobacterium rhinotracheale LMG $9086^{\mathrm{T}}$ (GenBank accession no. ORU87101) and $89 \%$ similar to that of Crocinitomix catalasitica NCIMB $1418^{\mathrm{T}}$ (GenBank accession no. AB078042) of the families Flavobacteriaceae and Cryomorphaceae, respectively. However, construction of a neighbourjoining phylogenetic tree clearly illustrated that strain RW $262^{\mathrm{T}}$ formed a monophyletic lineage with the family Cryomorphaceae, positioned between the families Flavobacteriaceae and Bacteroidaceae (Fig. 1). The phylogenetic analysis indicated that strain $\mathrm{RW} 262^{\mathrm{T}}$ represents a distinct genus within the Cryomorphaceae.

Strain RW $262^{\mathrm{T}}$ was similar to the members of the family Cryomorphaceae, sharing their apparent lack of nutritional versatility, inability to utilize carbohydrates and their existence as rod-shaped cells of variable length (Bowman et al., 2003). All members were also Gram-negative, catalasepositive, negative for indole production, and did not catalyse the hydrolysis of arginine, aesculin or starch. The $37 \cdot 2$ mol\% G + C content of strain RW $262^{\mathrm{T}}$ also fell within the 35-39 mol\% known range for the family Cryomorphaceae (Bowman et al., 2003). The differential characteristics of strain $\mathrm{RW} 262^{\mathrm{T}}$ and the type species of the four other Cryomorphaceae genera are shown in Table 2. Strain RW $262^{\mathrm{T}}$ was only capable of weak growth at $4{ }^{\circ} \mathrm{C}$, and was therefore not psychrotolerant as are other members of the family (Bowman et al., 2003). Strain RW262 ${ }^{\mathrm{T}}$ was also capable of DNA hydrolysis, whereas other members were not. In addition, strain RW $262^{\mathrm{T}}$ could be distinguished from Crocinitomix catalasitica NCIMB $1418^{\mathrm{T}}$ by its susceptibility to tetracycline and lack of growth at $30{ }^{\circ} \mathrm{C}$, from Brumimicrobium glaciale $\mathrm{IC} 156^{\mathrm{T}}$ by its aerobic metabolism and inability to reduce nitrate, from 


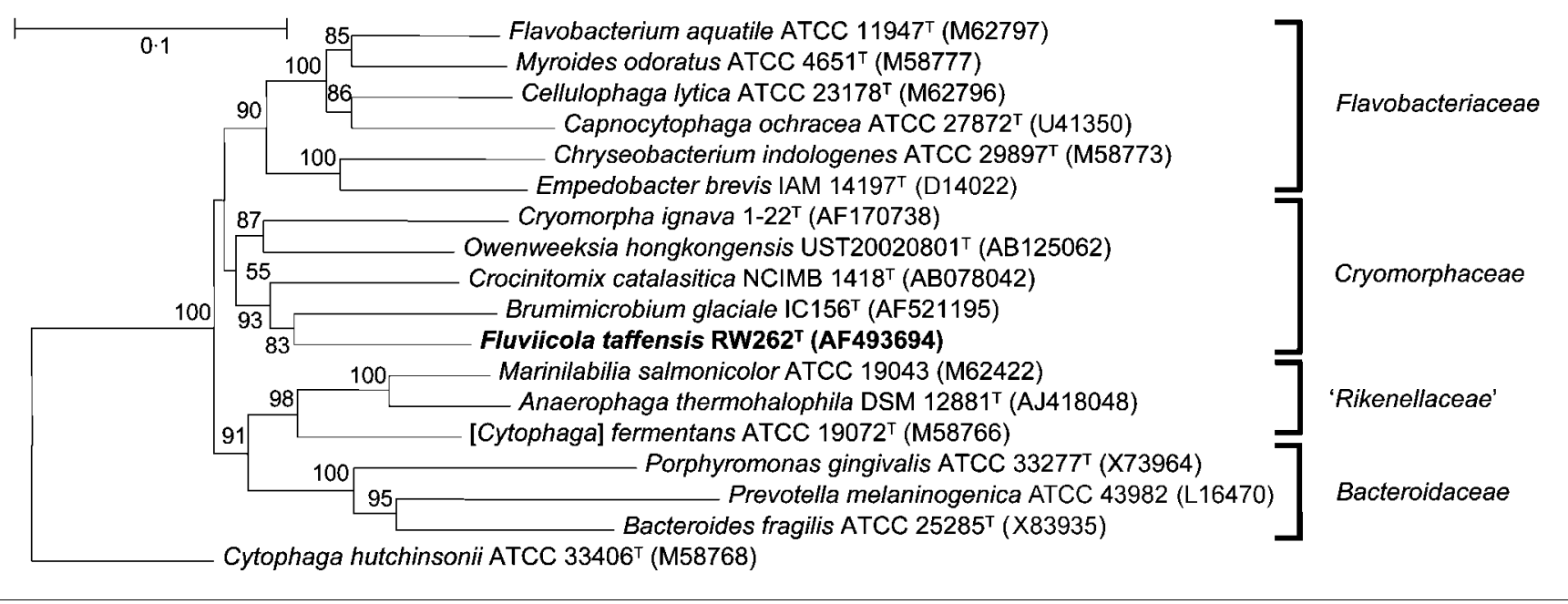

Fig. 1. A $16 \mathrm{~S}$ rRNA gene phylogenetic tree illustrating the relationship between strain $\mathrm{RW} 262^{\top}$ and other members of the phylum 'Bacteroidetes'. Sequences were retrieved from GenBank at the National Centre for Biotechnology Information (NCBI) web site (http://www.ncbi.nlm.nih.gov). Sequences were aligned using CLUSTAL W (Thompson et al., 1994) and the alignment was trimmed to $1300 \mathrm{bp}$. The tree was reconstructed with the neighbour-joining and Jukes-Cantor algorithms in TREECON (Van de Peer \& De Wachter, 1994), and was rooted with Cytophaga hutchinsonii ATCC $33406^{\top}$ (GenBank accession no. M58768). Bootstrap values from 100 replicate trees are shown at the nodes, and the bar represents $10 \%$ difference in nucleotide sequence.

Table 2. Differential phenotypic characteristics of $F$. taffensis RW $262^{\top}$ and type species of the genera Brumimicrobium, Cryomorpha, Crocinitomix and Owenweeksia of the family Cryomorphaceae

Strains: 1, F. taffensis RW262 ; 2, Crocinitomix catalasitica NCIMB $1418^{\mathrm{T}}$ (data from this study and Bowman et al., 2003); 3, B. glaciale IC156 ${ }^{\mathrm{T}}$ (Bowman et al., 2003); 4, Cryomorpha ignava 1-22 ${ }^{\mathrm{T}}$ (Bowman et al., 2003); 5, O. hongkongensis UST20020801 ${ }^{\mathrm{T}}$ (Lau et al., 2005). Abbreviations: +, positive; -, negative; ND, no data available; W, weakly positive; A, aerobic; F, facultatively anaerobic; S, sensitive; R, resistant. All strains grow at $20^{\circ} \mathrm{C}$ and are catalase-positive. All strains are negative for the Gram-test; indole production; growth on $10 \% \mathrm{NaCl}$; hydrolysis of arginine, aesculin and starch; acid production from glucose; and utilization of arabinose, mannose, mannitol, $\mathrm{N}$-acetylglucosamine, maltose, gluconate, malate and citrate.

\begin{tabular}{|c|c|c|c|c|c|}
\hline Characteristic & 1 & 2 & 3 & 4 & 5 \\
\hline Habitat & Freshwater & Marine & Marine & Marine & Marine \\
\hline Filaments & + & + & - & - & + \\
\hline Metabolism & A & A & $\mathrm{F}$ & A & A \\
\hline Gliding motility & + & + & + & - & + \\
\hline \multicolumn{6}{|l|}{ Growth at/on: } \\
\hline $4{ }^{\circ} \mathrm{C}$ & $\mathrm{W}$ & + & + & + & + \\
\hline $30^{\circ} \mathrm{C}$ & - & + & - & - & + \\
\hline $37^{\circ} \mathrm{C}$ & - & - & - & - & + \\
\hline $0 \% \mathrm{NaCl}$ & + & - & - & - & - \\
\hline $2 \cdot 5 \% \mathrm{NaCl}$ & - & + & + & - & + \\
\hline $5 \% \mathrm{NaCl}$ & - & + & + & - & + \\
\hline TSA & + & - & - & - & ND \\
\hline NA & + & - & - & - & ND \\
\hline MA2216 & - & + & + & + & ND \\
\hline DNA hydrolysis & + & - & - & $\mathrm{W}$ & - \\
\hline Gelatin hydrolysis & $\mathrm{W}$ & - & - & - & + \\
\hline Glucose utilization & - & - & + & - & - \\
\hline Nitrate reduction & - & - & + & - & - \\
\hline Oxidase activity & - & - & - & - & + \\
\hline Tetracycline susceptibility & $\mathrm{S}$ & $\mathrm{R}$ & ND & ND & $\mathrm{S}$ \\
\hline DNA $\mathrm{G}+\mathrm{C}$ content $(\mathrm{mol} \%)$ & $37 \cdot 2$ & 35 & $38-40$ & $36-37$ & $39-40$ \\
\hline
\end{tabular}


Cryomorpha ignava $1-22^{\mathrm{T}}$ by its gliding motility, and from Owenweeksia hongkongensis UST20020801 ${ }^{\mathrm{T}}$ by its inability to grow at $37^{\circ} \mathrm{C}$ or on $5 \% \mathrm{NaCl}$ and its lack of oxidase activity.

The main distinguishing feature was that strain RW $262^{\mathrm{T}}$ originated from a freshwater habitat and could not grow in the presence of $\mathrm{Na}^{+}$ions, whereas all other genera originated from marine habitats and had an absolute requirement for $\mathrm{Na}^{+}$ions or natural sea water. Consequently, RW $262^{\mathrm{T}}$ could grow on TSA and NA but not on MA2216, whereas the opposite was true for Crocinitomix catalasitica, B. glaciale and Cryomorpha ignava. Strain RW262 ${ }^{\mathrm{T}}$ was previously shown to form a monophyletic lineage with uncultivated bacteria represented in freshwater 16S rRNA gene libraries (O'Sullivan et al., 2004). This suggests that RW262 ${ }^{\mathrm{T}}$ may be a member of a freshwater clade within the family Cryomorphaceae which is distinct from the other marine members. Similar phylogenetic differentiation between freshwater and marine bacteria is commonplace within the closely related family Flavobacteriaceae, and was originally noted by Reichenbach et al. (1981). Specifically, the monophyletic branch representing the genus Flavobacterium contains mostly freshwater bacteria, whereas the monophyletic branch that represents many genera including Tenacibaculum, Polaribacter, Zobellia and Cellulophaga contains mostly marine bacteria.

The fatty acid profiles of strain RW $262^{\mathrm{T}}$ and the type species of the four other Cryomorphaceae genera were examined (Table 1). Cultivation conditions are known to influence fatty acid profiles (Männistö \& Puhakka, 2001) and therefore conditions were standardized as much as possible to allow comparison with the results of Bowman et al. (2003). In this study, strain RW262 ${ }^{\mathrm{T}}$ and Crocinitomix catalasitica were grown on MA2216 at $20^{\circ} \mathrm{C}$ for 3 days (minus $\mathrm{NaCl}$ for RW262 ${ }^{\mathrm{T}}$ ), whereas in the study by Bowman et al. (2003) Crocinitomix catalasitica, B. glaciale and Cryomorpha ignava were grown on MA2216 at $10-12{ }^{\circ} \mathrm{C}$ for 3-5 days. Overall, the fatty acids identified for Crocinitomix catalasitica were very similar between the two studies; however, there were some differences in the proportions of individual fatty acids (Table 1). Like many flavobacteria and cryomorpha, strain RW $262^{\mathrm{T}}$ contained high levels of C13-C17 branched-chain fatty acids (58.9\%), particularly saturated i15:0 (44.2\%) and unsaturated i15: $1 \omega 10 c$ $(11 \cdot 8 \%)$ fatty acids. There was also a large proportion of hydroxy fatty acids $(20 \cdot 4 \%)$, mainly composed of $3-\mathrm{OH}$ i17:0 $(12 \cdot 3 \%)$. The whole-cell fatty acid profiles shown in Table 1 clearly distinguish RW262 ${ }^{\mathrm{T}}$ from the other members of the Cryomorphaceae.

The results of the polyphasic taxonomic analysis indicated that strain RW $262^{\mathrm{T}}$ did not belong to any of the other genera currently described within the phylum 'Bacteroidetes'. We therefore propose that strain RW $262^{\mathrm{T}}$ should be classified as Fluviicola taffensis gen. nov., sp. nov.

\section{Description of Fluviicola gen. nov.}

Fluviicola [Flu.vi.i.co'la. L. masc. n. fluvius -ii river; L. suff. -cola (from L. masc. n. incola) inhabitant, dweller; N.L. masc. n. Fluviicola river dweller].

Non-flagellated, rod-shaped cells including rarer long filaments. Gram-negative. Strictly aerobic. Motile by gliding. Cell mass is pigmented yellow-orange and flexirubins are synthesized. Utilize carbohydrates for growth. Fatty acids contain a high proportion of branched-chain fatty acids

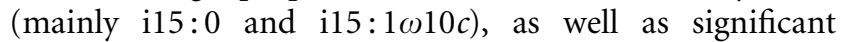
amounts of hydroxy fatty acids (mainly 3-OH i17:0). Isolated from freshwater environments, and do not grow in the presence of $\mathrm{Na}^{+}$ions. 16S rRNA gene sequence analysis indicates that the genus is a member of the family Cryomorphaceae in the phylum 'Bacteroidetes'. The type species is Fluviicola taffensis.

\section{Description of Fluviicola taffensis sp. nov.}

Fluviicola taffensis (taf.fen'sis. N.L. masc. adj. taffensis pertaining to the River Taff, a river in Wales).

Exhibits the following characteristics in addition to those properties described for the genus. Cells are $0 \cdot 4-0 \cdot 5 \mu \mathrm{m}$ wide and $1 \cdot 5-5 \cdot 7 \mu \mathrm{m}$ long, with rarer longer filaments of up to $51 \mu \mathrm{m}$ in length. Colonies are $1-5 \mathrm{~mm}$ in diameter, circular, flat, transparent, shiny, yellow-orange and creamy on high nutrient solid media. Catalase-positive. Oxidasenegative. Growth occurs at $4-25^{\circ} \mathrm{C}$, with an optimum at about $20^{\circ} \mathrm{C}$. Growth occurs on NA, PCA, TSA and DNASE agar, but not on MA2216, MacConkey agar or Cetrimide agar. Negative for nitrate and nitrite reduction. Indole is not produced. Negative for $\beta$-galactosidase, urease and xylanase activity. Capable of DNA hydrolysis and weak gelatin hydrolysis, but not hydrolysis of agar, arginine, aesculin or starch. Acid is not produced from glucose. Does not utilize glucose, arabinose, mannose, mannitol, $\mathrm{N}$ acetylglucosamine, maltose, gluconate, caprate, adipate, malate, citrate or phenyl acetate. Resistant to chloramphenicol, streptomycin and kanamycin, but susceptible to penicillin $\mathrm{G}$, ampicillin, rifampicin and tetracycline. The $\mathrm{G}+\mathrm{C}$ content of the DNA is $37 \cdot 2 \mathrm{~mol} \%$.

The type strain is $\mathrm{RW} 262^{\mathrm{T}}\left(=\mathrm{NCIMB} 13979^{\mathrm{T}}=\mathrm{DSM}\right.$ $\left.16823^{\mathrm{T}}\right)$, which was isolated from water of the River Taff, Cardiff, UK.

\section{Acknowledgements}

This work was supported by a Biotechnology and Biological Sciences Research Council (BBSRC) and Syngenta Industrial CASE Studentship awarded to Louise A. O'Sullivan. We would also like to thank Angela Marchbank for producing the electron micrographs.

\section{References}

Bernardet, J.-F., Segers, P., Vancanneyt, M., Berthe, F., Kersters, K. \& Vandamme, P. (1996). Cutting a Gordian knot: emended 
classification and description of the genus Flavobacterium, emended description of the family Flavobacteriaceae, and proposal of Flavobacterium hydatis nom. nov. (Basonym, Cytophaga aquatilis Strohl and Tait 1978). Int J Syst Bacteriol 46, 128-148.

Bernardet, J.-F., Nakagawa, Y. \& Holmes, B. (2002). Proposed minimal standards for describing new taxa of the family Flavobacteriaceae and emended description of the family. Int J Syst Evol Microbiol 52, 1049-1070.

Bowman, J. P., Mancuso Nichols, C. \& Gibson, J. A. E. (2003). Algoriphagus ratkowskyi gen. nov., sp. nov., Brumimicrobium glaciale gen. nov., sp. nov., Cryomorpha ignava gen. nov., sp. nov. and Crocinitomix catalasitica gen. nov., sp. nov., novel flavobacteria isolated from various polar habitats. Int J Syst Evol Microbiol 53, 1343-1355.

Brettar, I., Christen, R. \& Höfle, M. G. (2004). Belliella baltica gen. nov., sp. nov., a novel marine bacterium of the CytophagaFlavobacterium-Bacteroides group isolated from surface water of the central Baltic Sea. Int J Syst Evol Microbiol 54, 65-70.

Cashion, P., Holder-Franklin, M. A., McCully, J. \& Franklin, M. (1977). A rapid method for the base ratio determination of bacterial DNA. Anal Biochem 81, 461-466.

Cottrell, M. T. \& Kirchman, D. L. (2000). Community composition of marine bacterioplankton determined by $16 \mathrm{~S}$ rRNA gene clone libraries and fluorescence in situ hybridization. Appl Environ Microbiol 66, 5116-5122.

Cowan, S. T. \& Steel, K. J. (1975). Manual for the Identification of Medical Bacteria, 2nd edn. Cambridge: Cambridge University Press.

DeLong, E. F., Franks, D. G. \& Alldredge, A. L. (1993). Phylogenetic diversity of aggregate-attached vs. free-living marine bacterial assemblages. Limnol Oceanogr 38, 924-934.

Fautz, E. \& Reichenbach, H. (1980). A simple test for flexirubin-type pigments. FEMS Microbiol Lett 8, 87-91.

Glöckner, F. O., Fuchs, B. M. \& Amann, R. (1999). Bacterioplankton compositions of lakes and oceans: a first comparison based on fluorescence in situ hybridization. Appl Environ Microbiol 65, 3721-3726.

Gregerson, T. (1978). Rapid method for distinction of Gramnegative from Gram-positive bacteria. Eur J Appl Microbiol Biotechnol 5, 123-127.

Holmes, B. (1992). The genera Flavobacterium, Sphingobacterium, and Weeksella. In The Prokaryotes, 2nd edn, vol. 4, pp. 3620-3629. Edited by A. Balows, H. G. Trüper, M. Dworkin, W. Harder \& K.-H. Schleifer. Berlin: Springer.

Ivanova, E. P., Alexeeva, Y. V., Flavier, S., Wright, J. P., Zhukova, N. V., Gorshkova, N. M., Mikhailov, V. V., Nicolau, D. V. \& Christen, R. (2004). Formosa algae gen. nov., sp. nov., a novel member of the family Flavobacteriaceae. Int J Syst Evol Microbiol 54, 705-711.

Lane, D. J. (1991). 16S/23S rRNA sequencing. In Nucleic Acid Techniques in Bacterial Systematics, pp. 115-175. Edited by E. Stackebrandt \& M. Goodfellow. Chichester: Wiley.

Lau, K. W. K., Ng, C. Y. M., Ren, J., Lau, S. C. L., Qian, P.-Y., Wong, P.-K., Lau, T. C. \& Wu, M. (2005). Owenweeksia hongkongensis gen. nov., sp. nov., a novel marine bacterium of the phylum 'Bacteroidetes'. Int J Syst Evol Microbiol 55, 1051-1057.

Männistö, M. K. \& Puhakka, J. A. (2001). Temperature- and growthphase-regulated changes in lipid fatty acid structures of psychrotolerant groundwater Proteobacteria. Arch Microbiol 177, 41-46.

Mesbah, M., Premachandran, U. \& Whitman, W. B. (1989). Precise measurement of the $\mathrm{G}+\mathrm{C}$ content of deoxyribonucleic acid by highperformance liquid chromatography. Int J Syst Bacteriol 39, 159-167.
Nedashkovskaya, O. I., Suzuki, M., Vysotskii, M. V. \& Mikhailov, V. V. (2003a). Reichenbachia agariperforans gen. nov., sp. nov., a novel marine bacterium in the phylum Cytophaga-FlavobacteriumBacteroides. Int J Syst Evol Microbiol 53, 81-85.

Nedashkovskaya, O. I., Suzuki, M., Vysotskii, M. V. \& Mikhailov, V. V. (2003b). Vitellibacter vladivostokensis gen. nov., sp. nov., a new member of the phylum Cytophaga-Flavobacterium-Bacteroides. Int J Syst Evol Microbiol 53, 1281-1286.

Nedashkovskaya, O. I., Kim, S. B., Han, S. K. \& 7 other authors (2003c). Mesonia algae gen. nov., sp. nov., a novel marine bacterium of the family Flavobacteriaceae isolated from the green alga Acrosiphonia sonderi (Kütz) Kornm. Int J Syst Evol Microbiol 53, 1967-1971.

Nedashkovskaya, O. I., Kim, S. B., Han, S. K., Rhee, M. S., Lysenko, A. M., Falsen, E., Frolova, G. M., Mikhailov, V. V. \& Bae, K. S. (2004). Ulvibacter litoralis gen. nov., sp. nov., a novel member of the family Flavobacteriaceae isolated from the green alga Ulva fenestrata. Int J Syst Evol Microbiol 54, 119-123.

Nikitin, D. I., Strömpl, C., Oranskaya, M. S. \& Abraham, W.-R. (2004). Phylogeny of the ring-forming bacterium Arcicella aquatica gen. nov., sp. nov. (ex Nikitin et al. 1994), from a freshwater neuston biofilm. Int J Syst Evol Microbiol 54, 681-684.

O'Sullivan, L. A., Weightman, A. J. \& Fry, J. C. (2002). New degenerate Cytophaga-Flexibacter-Bacteroides-specific 16S ribosomal DNA-targeted oligonucleotide probes reveal high bacterial diversity in River Taff epilithon. Appl Environ Microbiol 68, 201-210.

O'Sullivan, L. A., Fuller, K. E., Thomas, E. M., Turley, C. M., Fry, J. C. \& Weightman, A. J. (2004). Distribution and culturability of the uncultivated 'AGG58 cluster' of the Bacteroidetes phylum in aquatic environments. FEMS Microbiol Ecol 47, 359-370.

Reichenbach, H., Kohl, W. \& Achenbach, H. (1981). The flexirubintype pigments, chemosystematically useful compounds. In The Flavobacterium-Cytophaga Group (Proceedings of the International Symposium on Yellow-Pigmented Gram-Negative Bacteria of the Flavobacterium-Cytophaga Group), pp. 101-108. Edited by $\mathrm{H}$. Reichenbach \& O. B. Weeks. Weinheim: Verlag Chemie.

Serrano-Carreon, L., Hathout, Y., Bensoussan, M. \& Belin, J. M. (1992). Quantitative separation of Trichoderma lipid classes on a bonded phase column. J Chromatogr 584, 129-133.

Smibert, R. M. \& Krieg, N. R. (1994). Phenotypic characterization. In Methods for General and Molecular Bacteriology, pp. 607-654. Edited by P. Gerhardt, R. G. E. Murray, W. A. Wood \& N. R. Krieg. Washington, DC: American Society for Microbiology.

Sohn, J. H., Lee, J.-H., Yi, H., Chun, J., Bae, K. S., Ahn, T.-Y. \& Kim, S.-J. (2004). Kordia algicida gen. nov., sp. nov., an algicidal bacterium isolated from red tide. Int J Syst Evol Microbiol 54, 675-680.

Thompson, J. D., Higgins, D. G. \& Gibson, T. J. (1994). CLUSTAL W: improving the sensitivity of progressive multiple sequence alignment through sequence weighting, position-specific gap penalties and weight matrix choice. Nucleic Acids Res 22, 4673-4680.

Van de Peer, Y. \& De Wachter, R. (1994). TREECON for Windows: a software package for the construction and drawing of evolutionary trees for the Microsoft Windows environment. Comput Appl Biosci 10, 569-570.

Van Trappen, S., Vandecandelaere, I., Mergaert, J. \& Swings, J. (2004). Gillisia limnaea gen. nov., sp. nov., a new member of the family Flavobacteriaceae isolated from a microbial mat in Lake Fryxell, Antarctica. Int J Syst Evol Microbiol 54, 445-448. 